\title{
MODEL PERPINDAHAN MASSA PADA EKSTRAKSI SAPONIN BIJI TEH DENGAN PELARUT ISOPROPIL ALKHOHOL 50\% DENGAN PENGONTAKAN SECARA DISPERSI MENGGUNAKAN ANALISIS DIMENSI
}

\author{
Susiana Prasetyo*) dan Felicia Yosephine \\ Jurusan Teknik Kimia Universitas Katolik Parahyangan \\ Jl. Ciumbuleuit 94, Bandung 40141, Telp./Fax : 022-2032700 \\ ${ }^{*}$ Penulis korespondensi: susianaprasetyo@ yahoo.com
}

\begin{abstract}
DIMENSIONAL ANALYSIS FOR MASS TRANSFER MODEL FOR SAPONIN FROM TEA SEEDS USING 50\% ISOPROPYL ALCOHOL SOLVENT IN A DISPERSION SYSTEM. Indonesia is one of the biggest tea producers in the world. According to the Deptan 2010, about 127712 hectares plantation land area produced 153971 tons of tea. Nevertheless, the utilization of tea is still restricted on the tea young sprouts. The tea seed itself which is very potential due to its bioactive ingredients has not been utilized yet. The seed contains 26\% saponin, 20-60\% oil, and $11 \%$ protein. Saponin is one of the bioactive components which has been used as an insecticide to kill pests on shrimps in the fishing industry, or additives for detergent industry, shampoo, beer drinks, foam on the fire department, and it can also be used as an organic fertilizer. In this research, tea seed saponin was obtained from the extraction of tea seed which was previously mechanically pressed using IPA $50 \%$ as the solvent in a $2 \mathrm{~L}$ batch extractor. The contact between solvent and the seed tea occurred via dispersion mechanism. The fixed variable during the extractions was mass solvent to mass feed ratios (20:1), while the studied variables were temperatures $\left(25-60^{\circ} \mathrm{C}\right)$, stirring speeds (100-400 rpm), and the sizes of the seeds $(-40+50$ mesh to $-100+200$ mesh). Extraction was carried out until equilibrium was reached. Extract was concentrated by vacuum evaporation at temperatures below $40^{\circ} \mathrm{C}$. Concentrated saponin was purified by sequential addition of ether; ethanol and petroleum ether in order to obtain pure saponin precipitated which is then dried using a tray drier at a temperature of $40^{\circ} \mathrm{C}$. In this study, a simple mass transfer model was developed in order to describe the solid-liquid extraction process of tea seed saponin. Based on the results of the dimensional analysis, the relationships between the volumetric mass transfer coefficient $\left(k_{L} a\right)$ at the interphase of solid-liquid surface and extraction variables can be expressed by the following equation $\frac{\mathrm{k}_{\mathrm{L}} \mathrm{a} \mathrm{d}_{\mathrm{p}}^{2}}{\mathrm{D}_{\mathrm{L}}}=2.2490\left[\frac{\mathrm{Nd} \mathrm{p}_{\mathrm{p}}^{2} \rho}{\mu}\right]^{0.4687}\left[\frac{\mu}{\rho \mathrm{D}_{\mathrm{L}}}\right]^{0.5855}\left[\frac{\mathrm{d}_{\mathrm{b}}}{\mathrm{d}_{\mathrm{p}}}\right]^{0.1217}$ with the average error is $3.7904 \%$.
\end{abstract}

Keywords: dimensional analysis; dispersion; extraction; isopropyl alcohol 50\%; mass transfer; saponin; tea seed

\begin{abstract}
Abstrak
Indonesia merupakan salah satu penghasil teh terbesar di dunia. Menurut data dari Deptan 2010, dengan luas lahan sebesar 127712 ha, Indonesia dapat menghasilkan produktivitas teh sebesar 153971 ton/tahun. Namun sayangnya, selama ini pemanfaatan tanaman teh di Indonesia masih terbatas pada pucuk daunnya saja. Bagian tanaman teh yang memiliki kandungan potensial namun belum dimanfaatkan adalah biji teh, mengandung 26\% saponin, 20-60\% minyak dan 11\% protein. Saponin merupakan salah satu komponen bioaktif yang telah dimanfaatkan sebagai insektisida pembasmi hama pada tambak udang, bahan baku industri deterjen, shampoo, minuman bir, pembentuk busa pada pemadam kebakaran, dan dapat dimanfaatkan pula sebagai pupuk organik. Pada penelitian ini, saponin biji teh diperoleh melalui ekstraksi biji teh pasca pengepresan menggunakan pelarut IPA 50\% secara batch di dalam sebuah ekstraktor berkapasitas 2 L. Pengontakan solvent dengan biji teh dilakukan secara dispersi. Pada penelitian ini, rasio massa pelarut terhadap massa umpan diset 20:1; temperatur divariasikan 25-60 ${ }^{\circ} \mathrm{C}$, kecepatan pengadukan
\end{abstract}


100-400 rpm, serta ukuran biji teh divariasikan -40+50 mesh s.d-100+200 mesh. Ekstraksi dilakukan hingga tercapai kesetimbangan. Ekstrak yang diperoleh dipekatkan menggunakan rotavapor vakum pada temperatur di bawah $40^{\circ} \mathrm{C}$. Ekstrak pekat saponin kasar yang didapat dimurnikan dengan penambahan eter, etanol dan petroleum eter secara bertahap sehingga diperoleh endapan saponin murni yang kemudian dikeringkan menggunakan tray drier pada temperatur $40^{\circ} \mathrm{C}$. Pada penelitian ini, model perpindahan massa sederhana dikembangkan untuk menggambarkan proses ekstraksi padat-cair saponin biji teh. Berdasarkan hasil analisis dimensi diperoleh hubungan antara koefisien perpindahan massa volumetrik $\left(k_{L} a\right)$ pada lapisan antar fasa padat-cair dengan variabel-variabel ekstraksi yang dinyatakan dalam persamaan bilangan tak berdimensi $\frac{\mathrm{k}_{\mathrm{L}} \mathrm{ad}_{\mathrm{p}}^{2}}{\mathrm{D}_{\mathrm{L}}}=2,2490\left[\frac{\mathrm{Nd} \mathrm{d}_{\mathrm{p}}^{2} \rho}{\mu}\right]^{0,4687}\left[\frac{\mu}{\rho \mathrm{D}_{\mathrm{L}}}\right]^{0,5855}\left[\frac{\mathrm{d}_{\mathrm{b}}}{\mathrm{d}_{\mathrm{p}}}\right]^{0,1217}$ dengan ralat rata-rata $3,7904 \%$.

Kata kunci: analisis dimensi; dispersi; ekstraksi; IPA 50\%; perpindahan massa; saponin; biji teh

\section{PENDAHULUAN Biji Teh}

Indonesia merupakan salah satu negara penghasil teh terbesar di dunia. Namun sayangnya, perkembangan produksi tanaman teh di Indonesia tidak diikuti dengan optimasi pemanfaatannya. Selama ini, pemanfaatan tanaman teh hanya terbatas pada bagian pucuk dan daun mudanya saja sebagai minuman kesehatan yang biasa dikenal dengan nama green tea, oolong tea, dan black tea. Padahal, biji yang terkandung dalam buah teh memiliki potensi untuk dimanfaatkan. Selama ini, biji teh kurang dilirik bahkan terlupakan. Dengan berkembangnya pembibitan teh melalui setek, biji teh yang dihasilkan dari tanaman teh yang diliarkan praktis hanya terbuang begitu saja. Produksi teh di Indonesia pada tahun 2010 tercatat mencapai 150000 ton (Setyamidjaja, 2000; Anonim, 2009). Menurut survey di perkebunan teh Gambung, 1 batang pohon teh liar dapat menghasilkan biji teh cukup besar, yaitu 8-12 kg/tahun.

Biji teh kering mengandung 26\% saponin, 20$60 \%$ minyak dan $11 \%$ protein. Biji teh merupakan sumber saponin terbesar, bahkan bila dibandingkan dengan sapindus rarak (lerak) yang telah dikenal sebagai sumber saponin selama ini (de Silva, 1972; Wickremasinghe, 1976; Musalam dan Yuliana, 1989). Ironisnya, Indonesia selama ini masih mengimpor bungkil biji teh dari Taiwan dan RRC sebagai pembasmi hama udang pada tambak-tambak yang tersebar di seluruh Indonesia. Penggalakan kembali budidaya tanaman buah teh, selain hanya berfokus pada peningkatan produksi dan mutu daunnya, menjadi alternatif yang menjanjikan untuk meningkatkan produktivitas tanaman teh. Penelitian ini mencoba untuk mengkaji pemanfaatan biji teh sebagai sumber saponin. Metode yang dipilih adalah ekstraksi padat cair menggunakan pelarut IPA $50 \%$.

\section{Saponin}

Saponin, berasal dari bahasa Latin sapo yang berarti sabun, merupakan senyawa aktif permukaan yang kuat dan mempunyai sifat khas dapat membentuk larutan koloidal dalam air dan membuih bila dikocok sehingga diaplikasikan biasa sebagai emulsifier pada pestisida, pembentuk buih pada tabung pemadam api, deterjen dan bir. Selain itu, saponin triterpenoida dalam camellia telah dibuktikan dapat meningkatkan fungsi kekebalan, aktivitas anti-bakteri dan antikuman, serta memiliki sifat anti mutasi dan anti oksidasi pada manusia dan hewan serta berfungsi sebagai pembasmi ikan liar pada budidaya udang (Musalam dan Yuliana, 1989; Evans, 2002).

Saponin termasuk golongan glikosida; merupakan metabolit sekunder yang banyak terdapat di alam; terdiri dari gugus gula yang berikatan dengan aglikon atau sapogenin membentuk kristal berwarna kuning pucat dan amorf; berasa pahit dan berbau menyengat; serta bersifat ampifilik dan polar. Gugus heksosa pada saponin dapat larut dalam air tetapi tidak larut dalam alkohol absolut, kloroform, eter dan pelarut organik non polar lainnya. Gugus triterpenoid aglikonnya dapat larut dalam lemak serta dapat membentuk emulsi dengan minyak dan resin. Saponin dapat dibedakan menjadi 2 macam berdasarkan struktur aglikonnya, yaitu tipe steroid dan triterpenoid. Kedua jenis saponin ini larut dalam air dan etanol namun tidak larut dalam eter (Evans, 2002).

Saponin biji teh termasuk golongan triterpenoid dan terdiri dari 7 komponen sapogenin. Teaseed saponin tersusun atas sapogenin $\left(\mathrm{C}_{30} \mathrm{H}_{50} \mathrm{O}_{6}\right)$, aglikon dan asam organik. Teaseed saponin termasuk dalam golongan saponin triterpen pentasiklik dengan rumus molekul $\mathrm{C}_{57} \mathrm{H}_{90} \mathrm{O}_{26}$ dan memiliki berat molekul sebesar 1191,28. Teaseed saponin murni tidak berwarna hingga kuning pucat, membentuk kristal, memiliki titik leleh $223-224^{\circ} \mathrm{C}$, dapat larut dengan mudah dalam larutan metanol, etanol, n-butanol, asam asetat glasial, dan piridin tetapi tidak larut dalam eter, kloroform dan aseton (Musalam dan Yuliana, 1989; Evans, 2002). Stuktur molekul teaseed sapogenin disajikan pada Gambar 1. 


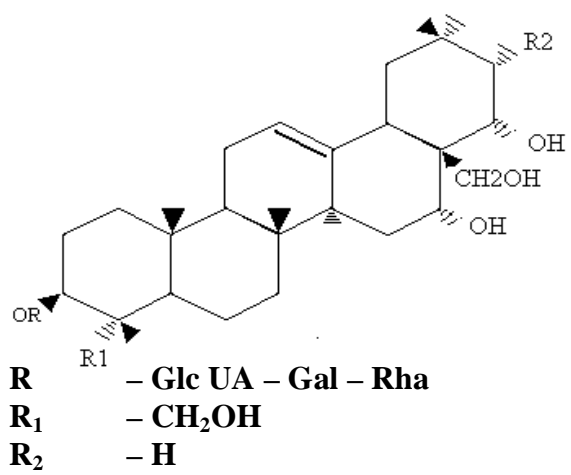

Gambar 1. Struktur molekul theasapogenin (de Silva, 1972; Clark, 2002)

\section{Ekstraksi Padat Cair}

Ekstraksi padat cair atau leaching merupakan suatu proses pemisahan satu atau beberapa komponen dari campurannya dalam padatan secara difusional dengan bantuan pelarut. Saat pengontakan padatan dengan pelarut, terjadi perpindahan sebagian solute ke dalam fasa cair (pelarut) secara difusional yang berlangsung hingga kesetimbangan tercapai. Cara pengontakan dapat dilakukan dengan mengaduk suspensi padatan di dalam tangki (dispersi) atau dengan menyusun padatan tersebut dalam suatu unggun tetap kemudian cairan pelarut mengalir di antara butiran padatan (imersi). Perpindahan massa berlangsung pada bidang kontak antara fasa padat dan fasa cair. Pengecilan ukuran padatan dilakukan untuk memperluas permukaan kontak dan memperkecil lintasan kapiler dalam padatan yang harus dilewati pelarut saat berdifusi sehingga mengurangi tahanan perpindahan massanya (Richardson dkk., 2002; Perry dan Green., 1997).

\section{Model Perpindahan Massa}

Aspek penting untuk mengevaluasi unjuk kerja proses ekstraksi padat-cair umumnya diturunkan dari percobaan kinetika ekstraksi tersebut. Hukum dasar kinetika dan difusi massa mendasari penurunan model matematika untuk memprediksi efektivitas proses difusi ekstraksi padat cair ini (Taralkar dan Garkal, 2010).

Model difusi massa sebagian besar senyawa fitokimia dikembangkan untuk menggambarkan proses ekstraksi padat-cair (Mohamad dkk., 2010). Proses ekstraksi bahan alam, seperti halnya senyawa fitokimia ini dapat digambarkan dalam beberapa tahapan berikut (Yuniwati dan Purwanti, 2008; Mohamad dkk., 2010; Asano, 2006; Richardson dkk., 2002):

1. pelarut berdifusi dari fasa curah ke permukaan padatan (difusi eksternal),

2. pelarut berdifusi dari permukaan padatan menuju pori-pori padatan (difusi internal),

3. solut terlarut ke dalam pelarut,

4. zat terlarut berdifusi dari dalam pori-pori padatan menuju permukaan padatan,
5. solut berdifusi dari permukaan padatan menuju fasa curah.

Senyawa fitokimia, seperti halnya saponin, berada di dalam sel. Hal ini menyebabkan proses ekstraksi senyawa fitokimia begitu sulit dan kompleks. Oleh karena itu, model matematika untuk ekstraksi padat cair senyawa fitokimia difokuskan pada proses difusi senyawa fitokimia tersebut. Kecepatan ekstraksi padat cair tergantung pada 2 tahapan pokok, yaitu difusi solute dari dalam bahan ekstraksi ke permukaan bahan ekstraksi (difusi internal) dan difusi solute dari permukaan bahan ekstraksi ke pelarut (difusi eksternal). Jika perbedaan kecepatan kedua tahap hampir sama, maka kecepatan ekstraksi ditentukan oleh kedua tahap tersebut. Jika Perbedaan kecepatan kedua tahapan cukup besar, maka kecepatan ekstraksi ditentukan oleh kecepatan proses yang lebih lambat (Mohamad dkk., 2010; Samun, 2008; Asano, 2006; Richardson dkk., 2002).

Ada 2 model untuk meninjau perpindahan massa pada ekstraksi padat cair (Mohamad dkk., 2010; Asano, 2006; Richardson dkk., 2002; Cacace dan Mazza, 2003):

\section{Distributed Model}

Pada distributed model, tahanan film ekstenal dianggap jauh lebih kecil daripada tahanan internal di dalam partikel sehingga difusi eksternal jauh lebih cepat daripada difusi internal. Akibatnya, laju ekstraksi dikendalikan oleh perpindahan massa internal. Konsentrasi solute di dalam bahan ekstraksi merupakan fungsi posisi dan diasumsikan tidak ada tahanan film. Profil konsentrasi distributed model disajikan pada Gambar 2.

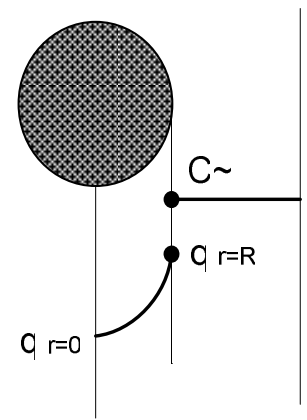

Gambar 2. Profil konsentrasi distributed model

\section{Lumped Model}

Model ini berlaku jika kecepatan ekstraksi ditentukan oleh difusi eksternal, dimana difusi internal diabaikan karena jauh lebih cepat dibandingkan difusi eksternal. Konsentrasi solute di dalam bahan ekstraksi dianggap seragam (bukan fungsi posisi). Profil konsentrasi lumped model disajikan pada Gambar 3.

Pemodelan difusi massa saponin biji teh pada penelitian ini mengadopsi dari beberapa penelitian terdahulu, dimana laju ekstraksi ditentukan oleh laju difusi massa eksternal dari padatan menuju fasa curah dengan beberapa asumsi sebagai berikut: (Handayani dkk., 2008; Yuniwati dan Purwanti, 2008; Mohamad dkk., 2010): 


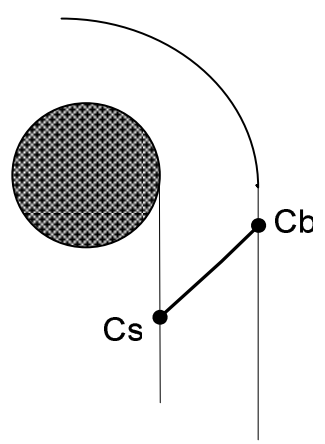

Gambar 3. Profil konsentrasi lumped model

a) konsentrasi solut di dalam padatan seragam sehingga tidak ada gradien konsentrasi di dalam padatan;

b) pelarut tercampur secara homogen sehingga tahanan perpindahan massa di fasa curah (cair) dapat diabaikan dan konsentrasi solut dalam pelarut hanya merupakan fungsi waktu; serta

c) tidak terjadi adsorpsi solut oleh padatan.

Model matematika untuk merepresentasikan perpindahan massa eksternal ekstraksi saponin biji teh pada penelitian ini mengikuti persamaan sebagai berikut (Handayani dkk., 2008; Smith, 1981; Yuniwati dan Purwanti, 2008; Samun, 2008):

massa zat terlarut $=$ aliran massa solute masuk ke dalam sistem

- aliran massa solute keluar dari sistem

+ massa solute yg tinggal di dlm pelarut

$$
\begin{gathered}
\frac{\mathrm{dm}_{\mathrm{A}}}{\mathrm{dt}}=0-0+\mathrm{k}_{\mathrm{L}} \mathrm{A}\left(\mathrm{C}_{\mathrm{AS}}-\mathrm{C}_{\mathrm{Ab}}\right) \\
\frac{\mathrm{dm}_{\mathrm{A}}}{\mathrm{dt}}=\mathrm{k}_{\mathrm{L}} \mathrm{A}\left(\mathrm{C}_{\mathrm{AS}}-\mathrm{C}_{\mathrm{Ab}}\right)
\end{gathered}
$$

Pada sistem batch, volume larutan dijaga konstan sehingga

$$
\mathrm{dm}_{\mathrm{A}}=\mathrm{VdC}_{\mathrm{A}}
$$

Substitusi persamaan (4) ke persamaan (3) menghasilkan

$$
\begin{gathered}
\mathrm{V} \frac{\mathrm{dC}_{\mathrm{A}}}{\mathrm{dt}}=\mathrm{k}_{\mathrm{L}} \mathrm{A}\left(\mathrm{C}_{\mathrm{AS}}-\mathrm{C}_{\mathrm{Ab}}\right) \\
\frac{\mathrm{dC}_{\mathrm{A}}}{\mathrm{dt}}=\frac{\mathrm{k}_{\mathrm{L}} \mathrm{A}}{\mathrm{V}}\left(\mathrm{C}_{\mathrm{AS}}-\mathrm{C}_{\mathrm{Ab}}\right) \\
\frac{\mathrm{d} \mathrm{C}_{\mathrm{A}}}{\mathrm{dt}}=\mathrm{k}_{\mathrm{L}} \mathrm{a}\left(\mathrm{C}_{\mathrm{AS}}-\mathrm{C}_{\mathrm{Ab}}\right)
\end{gathered}
$$

\section{Analisis Dimensi pada Perpindahan Massa}

Analisis dimensi berfungsi untuk memahami sifat fisika yang melibatkan besaran fisika yang berbeda. Berikut ini beberapa jenis bilangan tak berdimensi yang biasa digunakan pada perpindahan massa, yaitu (Geankoplis, 1993):

1. Bilangan Reynolds $\left(\mathrm{N}_{\mathrm{Re}}\right)$, menggambarkan keadaan atau rezim aliran fluida.

$$
\mathrm{N}_{\mathrm{Re}}=\frac{\mathrm{D} v \rho}{\mu}
$$

2. Bilangan Schmidt $\left(\mathrm{N}_{\mathrm{Sc}}\right)$, berhubungan dengan hydrodynamic layer dan mass-transfer boundary layer.

$$
\mathrm{N}_{\mathrm{Sc}}=\frac{\mu}{\rho \mathrm{D}_{\mathrm{L}}}
$$

3. Bilangan Sherwood $\left(\mathrm{N}_{\mathrm{Sh}}\right)$

$$
\mathrm{N}_{\mathrm{Sh}}=\mathrm{k}_{\mathrm{c}}^{\prime} \frac{\mathrm{L}}{\mathrm{D}_{\mathrm{L}}}
$$

Pada ekstraksi padat cair biasanya digunakan bilangan tak berdimensi $\mathrm{N}_{\mathrm{Sc}}, \mathrm{N}_{\mathrm{Sh}}$, dan $\mathrm{N}_{\mathrm{Re}}$.

Analisis dimensi dapat diselesaikan menggunakan metode Buckingham. Variabel-variabel yang memberikan pengaruh terhadap harga $\mathrm{k}_{\mathrm{L}} \mathrm{a}$ pada proses ekstraksi padat cair dengan kontak dispersi, yaitu: densitas larutan $\left(\rho, \mathrm{kg} / \mathrm{m}^{3}\right)$, viskositas larutan $(\mu$, $\mathrm{kg} / \mathrm{m} . \mathrm{s})$, difusivitas larutan $\left(\mathrm{D}_{\mathrm{L}}, \mathrm{m}^{2} / \mathrm{s}\right)$, diameter pengaduk (dp, m), diameter bahan ekstraksi (db, m), dan kecepatan pengadukan $\left(\mathrm{N}, \mathrm{s}^{-1}\right)$. Hubungan antara variabel-variabel di atas dapat dinyatakan dengan persamaan (Yuniwati dan Purwanti, 2008; Treyball, 1981; Rusell dan Denn, 1972):

$$
\begin{gathered}
k_{L} a=f\left(\rho, \mu, D_{L}, d p, d b, N\right) \\
k_{L} a=K \cdot \rho^{C 1} \cdot \mu^{C 2} \cdot D_{L}^{C 3} \cdot d p^{C 4} \cdot d b^{C 5} \cdot N^{C 6}
\end{gathered}
$$

dengan:

$\rho=\frac{\mathrm{M}}{\mathrm{L}^{3}} ; \mu=\frac{\mathrm{M}}{\mathrm{LT}} ; \mathrm{D}_{\mathrm{L}}=\frac{\mathrm{L}^{2}}{\mathrm{~T}} ; \mathrm{d}_{\mathrm{p}}=\mathrm{L} ; \mathrm{d}_{\mathrm{b}}=\mathrm{L} ; \mathrm{N}=\frac{1}{\mathrm{~T}}$

Hubungan persamaan (13) disubstitusi pada persamaan (12), sehingga didapat:

$\mathrm{T}^{-1}=\mathrm{K}\left(\mathrm{ML}^{-3}\right)^{\mathrm{C} 1}\left(\mathrm{ML}^{-1} \mathrm{~T}^{-1}\right)^{\mathrm{C} 2}\left(\mathrm{~L}^{2} \mathrm{~T}^{-1}\right)^{\mathrm{C} 3}(\mathrm{~L})^{\mathrm{C} 4}(\mathrm{~L})^{\mathrm{C} 5}\left(\mathrm{~T}^{-1}\right)^{\mathrm{C} 6}(14)$ Pangkat tiap dimensi untuk ruas kiri dan kanan dari persamaan di atas harus sama, maka diperoleh:

$\mathrm{M}: 0=\mathrm{C} 1+\mathrm{C} 2$

$\mathrm{L}: 0=-3 \mathrm{C} 1-\mathrm{C} 2+2 \mathrm{C} 3+\mathrm{C} 4+\mathrm{C} 5$

$\mathrm{T}:-1=-\mathrm{C} 2-\mathrm{C} 3-\mathrm{C} 6$

Persamaan (15), (16), dan (17) saling disubtitusi sehingga didapat beberapa hubungan pangkat-pangkat tersebut:

$$
\begin{gathered}
\mathrm{C} 1=-\mathrm{C} 2 \\
\mathrm{C} 3=1+\mathrm{C} 1-\mathrm{C} 6 \\
\mathrm{C} 4=-2-\mathrm{C} 5+2 \mathrm{C} 6
\end{gathered}
$$

Persamaan (18), (19), dan (20) disubstitusi ke persamaan (12):

$$
\begin{aligned}
& \mathrm{k}_{\mathrm{L}} \mathrm{a}=\mathrm{K} \cdot \rho^{\mathrm{C} 1} \cdot \mu^{-\mathrm{C} 1} \cdot \mathrm{D}_{\mathrm{L}}{ }^{1+\mathrm{C} 1+\mathrm{C} 6} \cdot \mathrm{dp}^{-2-\mathrm{C} 5+2 \mathrm{C} 6} \cdot \mathrm{db}^{\mathrm{C} 5} \cdot \mathrm{N}^{\mathrm{C} 6}(21) \\
& \frac{\mathrm{k}_{\mathrm{L}} \mathrm{ad}_{\mathrm{p}}^{2}}{\mathrm{D}_{\mathrm{L}}}=\mathrm{K}\left[\frac{\rho \mathrm{D}_{\mathrm{L}}}{\mu}\right]^{\mathrm{C} 1}\left[\frac{\mathrm{d}_{\mathrm{b}}}{\mathrm{d}_{\mathrm{p}}}\right]^{\mathrm{C} 5}\left[\frac{\mathrm{Nd}_{\mathrm{p}}^{2}}{\mathrm{D}_{\mathrm{L}}}\right]^{\mathrm{C} 6}\left[\frac{\mu}{\rho}\right]^{\mathrm{C} 6}\left[\frac{\rho}{\mu}\right]^{\mathrm{C} 6} \\
& \frac{\mathrm{k}_{\mathrm{L}} \mathrm{ad}_{\mathrm{p}}^{2}}{\mathrm{D}_{\mathrm{L}}}=\mathrm{K}\left[\frac{\rho \mathrm{D}_{\mathrm{L}}}{\mu}\right]^{\mathrm{C} 1}\left[\frac{\mathrm{d}_{\mathrm{b}}}{\mathrm{d}_{\mathrm{p}}}\right]^{\mathrm{C} 5}\left[\frac{\mathrm{Nd}_{\mathrm{p}}^{2} \rho}{\mu}\right]^{\mathrm{C} 6}\left[\frac{\mu}{\rho D_{\mathrm{L}}}\right]^{\mathrm{C} 6} \\
& \frac{\mathrm{k}_{\mathrm{L}} \mathrm{ad}_{\mathrm{p}}^{2}}{\mathrm{D}_{\mathrm{L}}}=\mathrm{K}\left[\frac{\mathrm{d}_{\mathrm{b}}}{\mathrm{d}_{\mathrm{p}}}\right]^{\mathrm{C} 5}\left[\frac{\mathrm{Nd}_{\mathrm{p}}^{2} \rho}{\mu}\right]^{\mathrm{C} 6}\left[\frac{\mu}{\rho \mathrm{D}_{\mathrm{L}}}\right]^{\mathrm{C} 6-\mathrm{C}} \\
& \frac{\mathrm{k}_{\mathrm{L}} \mathrm{ad}_{\mathrm{p}}^{2}}{\mathrm{D}_{\mathrm{L}}}=\mathrm{K}\left[\frac{\mathrm{d}_{\mathrm{b}}}{\mathrm{d}_{\mathrm{p}}}\right]^{\mathrm{a}}\left[\frac{\mathrm{Nd}_{\mathrm{p}}^{2} \rho}{\mu}\right]^{\mathrm{b}}\left[\frac{\mu}{\rho D_{\mathrm{L}}}\right]^{\mathrm{c}} \\
& \mathrm{N}_{\mathrm{Sh}}=\mathrm{K}\left[\frac{\mathrm{d}_{\mathrm{b}}}{\mathrm{d}_{\mathrm{p}}}\right]^{\mathrm{a}} \mathrm{N}_{\mathrm{Re}}{ }^{\mathrm{b}} \mathrm{N}_{\mathrm{Sc}}{ }^{\mathrm{c}}
\end{aligned}
$$


Harga difusivitas solute ke dalam pelarut $\left(\mathrm{D}_{\mathrm{L}}\right)$ didekati dengan persamaan Polson (Geankoplis, 1993),

$$
\mathrm{D}_{\mathrm{L}}=\frac{9,4 \times 10^{-15} \mathrm{~T}}{\mu\left(\mathrm{M}_{\mathrm{A}}^{1 / 3}\right)}
$$

\section{METODE PENELITIAN}

Bahan baku biji teh yang digunakan merupakan varietas Assamica, didapatkan dari perkebunan teh Gambung, Jawa Barat. Bahan kimia lainnya adalah pelarut isopropil alkhohol teknis, serta aquadest. Ekstraksi dilakukan di dalam sebuah ekstraktor bacth berkapasitas $2 \mathrm{~L}$ seperti disajikan pada Gambar 4.

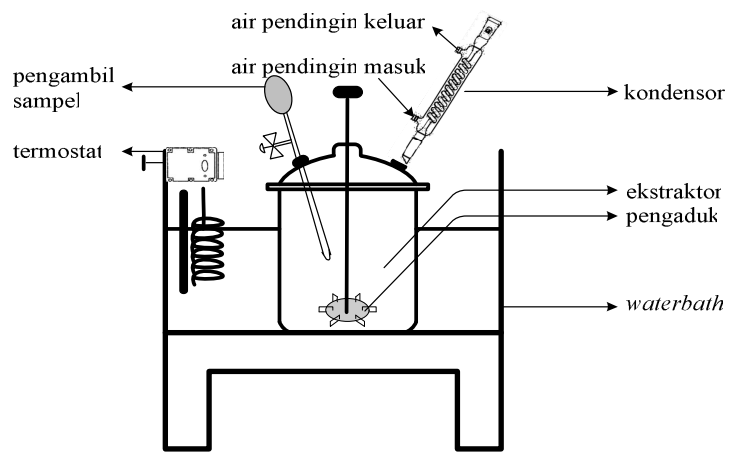

Gambar 4. Ekstraktor batch

Buah teh segar dikeringkan dengan cara dijemur di bawah sinar matahari hingga kering (secara visual terlihat perubahan warna buah teh dari hijau muda menjadi coklat tua dan daging buah merekah). Daging buah dan tempurung biji dipisahkan dari inti biji. Inti biji yang memenuhi standar (bebas jamur, tidak terserang kepik biji, tidak lapuk, segar, berukuran cukup besar dengan diameter $\geq 1 \mathrm{~cm}$ dan berwarna kuning pucat) dipilih sebagai bahan baku penelitian ini. Inti biji pilihan dikeringkan hingga diperoleh kadar air inti biji teh $<10 \%$. Biji teh kering ini dapat langsung diproses ataupun disimpan pada keadaan atmosferik tanpa penurunan kualitas secara signifikan.

Penentuan model difusi massa dilakuan dengan cara memvariasikan variabel ekstraksi berupa temperatur $\left(25,40\right.$ dan $\left.60^{\circ} \mathrm{C}\right)$, kecepatan pengadukan $(100,150,200 \mathrm{rpm})$, serta ukuran biji teh $(-40+50$;
$-60+80$ dan $-100+200$ mesh). Rasio serbuk biji teh terhadap pelarut IPA $50 \%$ di-set sebesar 1:20 g/mL. Ekstraksi dilakukan hingga kesetimbangan tercapai. Ekstrak dipekatkan menggunakan rotavapor vakum pada temperatur $<40^{\circ} \mathrm{C}$. Ekstrak pekat yang mengandung saponin kasar tersebut dimurnikan dengan penambahan eter, etanol, dan petroleum eter secara bertahap untuk memperoleh endapan saponin murni (Raech dan Tracey, 1995). Endapan saponin murni yang diperoleh dikeringkan dalam tray drier sehingga didapatkan serbuk saponin murni yang kering. Konsentrasi saponin dalam ekstrak (g/g) dapat diketahui secara gravimetri dengan cara membagi massa saponin yang diperoleh dengan massa sample. Penentuan nilai $\mathrm{k}_{\mathrm{L}}$ a dengan cara integrasi persamaan (7). Koefisien pangkat pada bilangan tak berdimensi ditentukan dengan metode multi regresi linier persamaan (28) berikut:

$$
\ln \mathrm{N}_{\mathrm{Sh}}=\ln \mathrm{K}+\mathrm{a} \ln \mathrm{N}_{\mathrm{Re}}+\mathrm{b} \ln \mathrm{N}_{\mathrm{Sc}}+\mathrm{c} \ln \frac{\mathrm{d}_{\mathrm{b}}}{\mathrm{d}_{\mathrm{p}}}
$$

\section{HASIL DAN PEMBAHASAN Laju Perpindahan Massa pada Ekstraksi Saponin Biji Teh}

Koefisien perpindahan massa merupakan konstanta laju difusi yang berkaitan dengan laju perpindahan massa (fluks massa), luas permukaan perpindahan massa, dan gradien konsentrasi sebagai driving force. Laju perpindahan massa berbanding lurus dengan driving force dan berbanding terbalik dengan tahanan, seperti yang ditunjukkan pada persamaan (7).

Semakin kecil tahanan (yang dihasilkan dari nilai $\mathrm{k}_{\mathrm{L}} \mathrm{a}$ yang semakin besar) maka laju perpindahan massa akan semakin besar, dan berlaku sebaliknya. Semakin besar resistant (yang dihasilkan dari nilai $\mathrm{k}_{\mathrm{L}} \mathrm{a}$ yang semakin kecil) maka laju perpindahan massa akan semakin kecil. Oleh karena itu nilai $\mathrm{k}_{\mathrm{L}} \mathrm{a}$ secara tidak langsung menunjukkan laju ekstraksi yang terjadi. Data koefisien laju ekstraksi saponin biji teh pada variasi temperatur ekstraksi, kecepatan pengadukan dan rasio massa biji teh/volume pelarut disajikan pada Tabel 1 sedangkan profilnya disajikan pada Gambar 5 s.d 7.

Tabel 1. Koefisien perpindahan massa ekstraksi saponin biji teh pada variasi temperatur ekstraksi, kecepatan pengadukan dan rasio massa biji teh/volume pelarut

\begin{tabular}{ccccc}
\hline $\begin{array}{c}\text { Ukuran partikel } \\
(\text { mesh })\end{array}$ & $\begin{array}{c}\text { Temperatur ektraksi } \\
\left({ }^{\circ} \mathrm{C}\right)\end{array}$ & $\begin{array}{c}\text { Kecepatan pengadukan } \\
(\mathrm{rpm})\end{array}$ & $\begin{array}{c}\text { Rasio massa biji teh: volume } \\
\text { pelarut }(\mathrm{g} / \mathrm{mL})\end{array}$ & $\mathrm{k}_{\mathrm{L}} \mathrm{a}\left(\mathrm{min}^{-1}\right)$ \\
\hline$-40+60$ & 25 & 200 & $1: 20$ & 0,047 \\
$-60+80$ & 25 & 200 & $1: 20$ & 0,041 \\
$-100+200$ & 25 & 200 & $1: 20$ & 0,048 \\
$-40+60$ & 25 & 100 & $1: 20$ & 0,04 \\
$-40+60$ & 40 & 100 & $1: 20$ & 0,041 \\
$-40+60$ & 60 & 100 & $1: 20$ & 0,046 \\
$-100+200$ & 60 & 100 & $1: 20$ & 0,042 \\
$-100+200$ & 60 & 150 & $1: 20$ & 0,039 \\
$-100+200$ & 60 & 200 & $1: 20$ & 0,079 \\
\hline
\end{tabular}




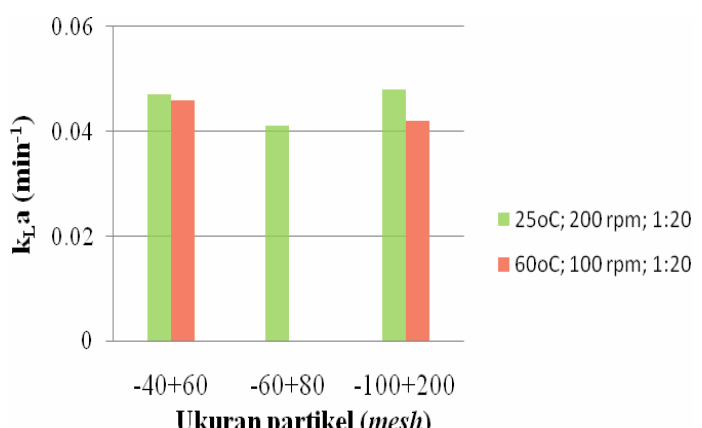

Gambar 5. Profil $\mathrm{k}_{\mathrm{L}}$ a pada variasi ukuran partikel

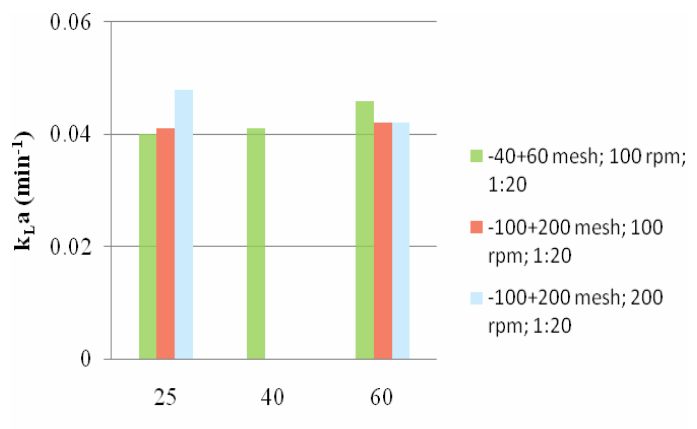

Temperatur ekstraksi $\left({ }^{\circ} \mathrm{C}\right)$

Gambar 6. Profil $\mathrm{k}_{\mathrm{L}}$ a pada variasi temperatur ekstraksi

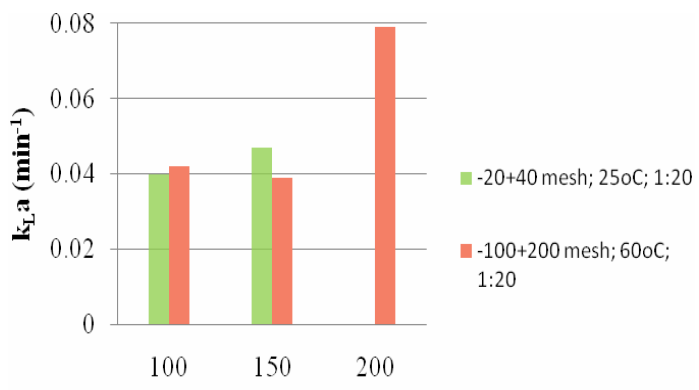

Kecepatan penga dukan (rpm)

Gambar 7. Profil $\mathrm{k}_{\mathrm{L}}$ a pada variasi kecepatan pengadukan

Berdasarkan hasil yang tersaji pada Tabel 1 dan Gambar 5 s.d 7 dapat dijelaskan sebagai berikut:

1) Semakin kecil ukuran partikel biji teh, nilai $k_{L} a$ cenderung meningkat karena bertambahnya luas permukaan kontak antara pelarut dengan partikel sehingga difusi massa pun meningkat.

2) Semakin tinggi temperatur ekstraksi, nilai $\mathrm{k}_{\mathrm{L}} \mathrm{a}$ cenderung meningkat karena viskositas pelarut berkurang sehingga difusi pelarut ke dalam padatan pun meningkat. Selain itu, semakin tinggi temperatur juga akan meningkatkan difusivitas solute ke dalam pelarut sehingga difusi massa pun meningkat.

3) Semakin tinggi kecepatan pengadukan cenderung meningkatkan ${ }_{\mathrm{kL}} \mathrm{a}$. Pengadukan memberikan gaya mekanik pada campuran sehingga kontak antara padatan dan pelarut menjadi baik dan laju difusi akan meningkat.

\section{Model Difusi Massa pada Ekstraksi Saponin Biji} Teh

Persamaan tidak berdimensi tidak bergantung pada skala geometri, sehingga dapat dipergunakan untuk keperluan scale up. Dengan menggunakan persamaan tidak berdimensi, skala geometri berbeda namun memiliki kinerja yang sama. Oleh karena itu digunakan analisis dimensi untuk menyusun model perpindahan massa yang dapat digunakan untuk merancang ekstraktor berpengaduk. Dari analisis dimensi diperoleh hubungan antara koefisien perpindahan massa volumetrik $\left(\mathrm{k}_{\mathrm{L}} \mathrm{a}\right)$ dengan variabelvariabel yang mempengaruhinya yang dinyatakan dalam persamaan bilangan tak berdimensi sebagai berikut:

$$
\frac{\mathrm{k}_{\mathrm{L}} \mathrm{ad}_{\mathrm{p}}^{2}}{\mathrm{D}_{\mathrm{L}}}=2,2490\left[\frac{\mathrm{Nd} \mathrm{d}_{\mathrm{p}}^{2} \rho}{\mu}\right]^{0,4687}\left[\frac{\mu}{\rho \mathrm{D}_{\mathrm{L}}}\right]^{0,5855}\left[\frac{\mathrm{d}_{\mathrm{b}}}{\mathrm{d}_{\mathrm{p}}}\right]^{0,1217}
$$

dengan ralat rata-rata $3,7904 \%$.

\section{Profil Bilangan Sherwood $\left(\mathbf{N}_{\mathrm{Sh}}\right)$ terhadap Bilangan Reynold $\left(\mathbf{N}_{\mathbf{R e}}\right)$}

Profil bilangan Sherwood terhadap bilangaan Reynold disajikan pada Gambar 8. Semakin tinggi bilangan Reynold maka bilangan Sherwood juga semakin meningkat. Hal ini disebabkan karena kecepatan pengadukan yang besar menyebabkan turbulensi meningkat sehingga kontak antara padatan dengan pelarut menjadi baik akibat menipisnya lapisan film yang mengeliling padatan. Akibatnya luas permukaan transfer massa pun meningkat dan perpindahan massanya juga semakin baik.

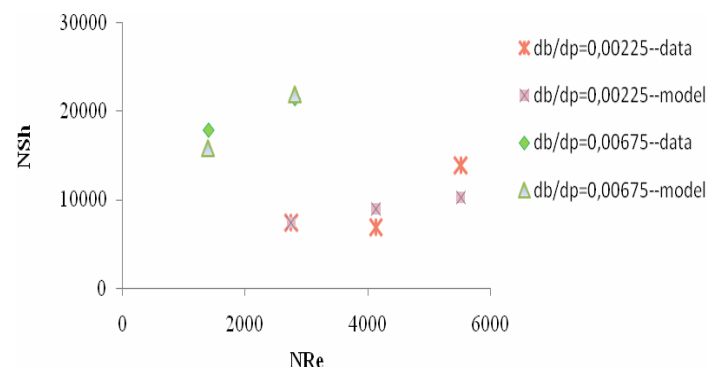

Gambar 8. Profil Bilangan Sherwood terhadap bilangan Reynold pada variasi diameter partikel

\section{Profil Bilangan Sherwood $\left(\mathbf{N}_{\mathrm{Sh}}\right)$ terhadap Bilangan Schmidt}

Profil bilangan Sherwood terhadap bilangaan Schmidts disajikan pada Gambar 9. Bilangan Schmidt mengacu kepada sifat fisik bahan yang terlibat di dalam ekstraksi padat-cair ini. Semakin tinggi bilangan Schmidt maka bilangan Sherwood semakin meningkat. Hal ini disebabkan karena peningkatan bilangan Schmidts menunjukkan peningkatan pergerakan ataupun difusivitas yang menyebabkan pelarut lebih mudah berdifusi ke fasa padatan dan 
solut pun lebih mudah berdifusi dan terlarut ke dalam fasa pelarut sehingga perpindahan massanya juga semakin baik.

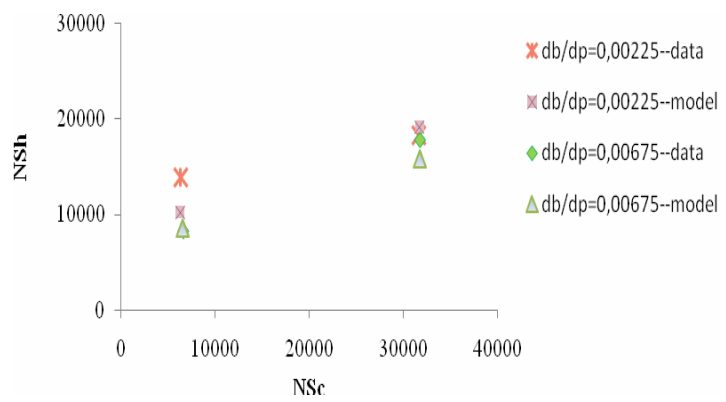

Gambar 9. Profil bilangan Sherwood terhadap bilangan Schmidt pada variasi diameter partikel

Profil Bilangan Sherwood $\left(\mathbf{N}_{\mathrm{Sh}}\right)$ terhadap $\frac{\mathrm{d}_{\mathrm{b}}}{\mathrm{d}_{\mathrm{p}}}$ Profil bilangan Sherwood terhadap $\frac{\mathrm{d}_{\mathrm{b}}}{\mathrm{d}_{\mathrm{p}}}$ disajikan pada Gambar 10. Semakin kecil ukuran biji teh seharusnya menyebabkan perpindahan massa yang semakin besar akibat meningkatnya luas kontak antara padatan dan pelarut. Selain itu, perlakuan mekanik pada saat pengecilan ukuran seharusnya akan meningkatkan perusakan dinding sel biji teh sehingga memudahkan pelarut berdifusi ke dalam padatan dan memudahkan pula difusi saponin ke dalam pelarut. Pada ukuran biji teh yang terlalu kecil juga terjadi peningkatan difusi komponen lain, seperti minyak yang justru meningkatkan tahanan perpindahan massa saponin ke dalam pelarut.

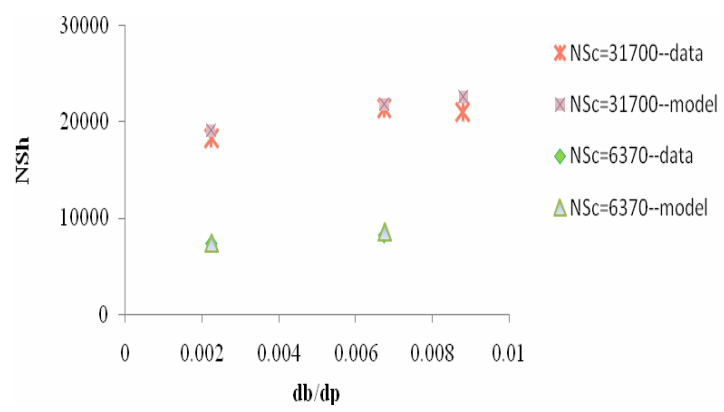

Gambar 10. Profil bilangan Sherwood terhadap $\frac{d_{b}}{d_{p}}$ pada variasi bilangan Schmidt

\section{KESIMPULAN}

Pengecilan ukuran partikel, peningkatan temperatur ekstraksi dan kecepatan pengadukan akan meningkatkan koefisien perpindahan massa pada ekstraksi saponin biji teh menggunakan pelarut isopropil alkhohol 50\%. Hubungan antara koefisien perpindahan massa volumetrik $\left(\mathrm{k}_{\mathrm{L}} \mathrm{a}\right)$ dengan variabel- variabel ekstraksi yang mempengaruhi dinyatakan dalam persamaan bilangan tak berdimensi sebagai berikut:

$$
\frac{\mathrm{k}_{\mathrm{L}} \mathrm{ad}_{\mathrm{p}}^{2}}{\mathrm{D}_{\mathrm{L}}}=2,2490\left[\frac{\mathrm{Nd}_{\mathrm{p}}^{2} \rho}{\mu}\right]^{0,4687}\left[\frac{\mu}{\rho \mathrm{D}_{\mathrm{L}}}\right]^{0,5855}\left[\frac{\mathrm{d}_{\mathrm{b}}}{\mathrm{d}_{\mathrm{p}}}\right]^{0,1217}
$$

dengan ralat rata-rata $3,7904 \%$.

\section{DAFTAR NOTASI}

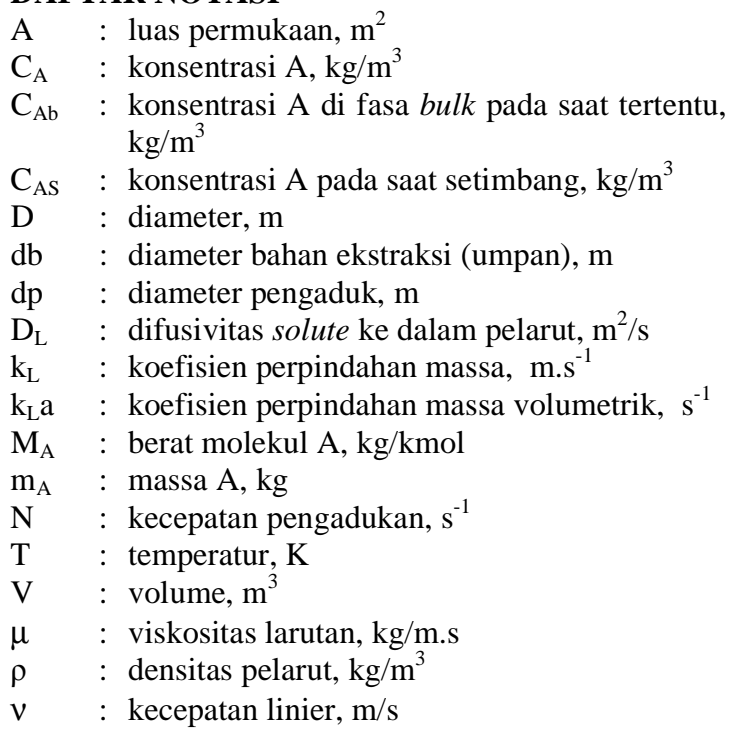

\section{DAFTAR PUSTAKA}

Anonim, (2009), Tea, http://en.wikipedia.org/wiki/ Tea, didownload 19 Januari 2010.

Asano, K., (2006), Mass Transfer, Wiley-Vch Verlag GmbH \& Co. KGaA,Weinheim, pp.1-51.

Cacace, J.E. and Mazza, G., (2003), Mass Transfer Process During Extraction of Phenolic Compounds from Milled Berries, Food Eng., 59, pp. 379-389.

De Silva, U.L.L. and Roberts, G.R., (1972), The Effect of Cultural Operations on the Composition of the Xylem Sap of Tea Plants Recovering From Pruning, Final Project, Tea Research Institute of Srilanka.

Evans, C.W., (2002), Trease and Evans' Pharmacognosy, 15, Saunders Company, New York, pp. 289-290, 297-298.

Geankoplis, C.J., (1993), Transport Processes and Unit Operations, $3^{\text {rd }}$ Edition, Prentice-Hall Inc., New Jersey, pp. 405, 437-438, 474-475.

Handayani, A.D., Sutrisno, Indraswati, N., and Ismadji, S., (2008), Extraction of Astaxanthin from Giant Tiger (Panaeus monodon) Shrimp Waste Using Palm Oil: Studies of Extraction Kinetics and Thermodynamics, Biore. Tech.,99, pp. 4414-4419. 
Mohamad, M., Ali, M.W. and Ahmad, A., (2010), Modelling for Extraction of Major Phytochemical Components from Eurycoma longifolia, Journal of Applied Science, 10 (21), pp. 2572-2577.

Musalam dan Yuliana, (1989), Pemanfaatan Saponin Biji Teh Pembasmi Hama Udang, Pusat Penelitian Perkebunan, Gambung.

Perry, R.H. and Green, D.W., (1997), Perry's Chemical Engineers' Handbook, $7^{\text {th }}$ Edition, McGrawHill Companies, Inc., United States of America, pp. $18-55-18-58$.

Raech, K. and Tracey, N.V., (1995), Modern Methods of Plant Analysis vol III, Berlin, Springer Verlag.

Richardson, J.F., Harker, J.F., and Backhurst, J.R., (2002), Particle Technology and Separation Processes in Coulson and Richardson's Chemical Engineering, 5 (2), Butterworth-Heinemann, Great Britain, pp. 504538.

Rusell, T.W.F and Denn, M.M., (1972), Intoduction to Chemical Engineering Analysis, John Wiley\&Sons, Inc, New York, London, Sydney, Toronton.

Samun, (2008), Koefisien Transfer Massa Volumetris Ekstraksi Zat Warna Alami Dari Rimpang Kunyit
(Kurkuminoid) Di Dalam Tangki Berpengaduk, Ekuilibrium , 7.

Setyamidjaja, (2000), Teh: Budidaya dan Pengolahan Pascapanen, Kanisius, Yogyakarta, hal. 11-19, 23-24, 29.

Smith, J.M., (1981), Chemical Engineering Kinetics, Mc. Graw Hill Book Co., Inc., Singapore.

Taralkar, S.V. and Garkal, D.J., (2010), Solid-Liquid Extraction Process of Active Ingredients from Medicinal Plants Mathematical Models, International Journal of chemical Sciences and Applications, 1 (2), pp. 82-85.

Treybal, R.E., (1981), Mass - Transfer Operations, $3^{\text {rd }}$ Ed., McGraw-Hill Book Company, Singapore, pp. 488-489.

Wickremasinghe, R.L., (1972), By-products of Tea, Tea $O, 43$ (3), pp. 85-87.

Yuniwati, M. dan Purwanti, A., (2008), Optimasi Kondisi Ekstraksi Minyak Biji Pepaya, Jurnal Teknologi Technoscientia, 1 (1), hal.78-84. 